\title{
Analysis of Energy Intensive Enterprises under EU Emission Trading System in Latvia
}

\author{
Dace Zahare ${ }^{1}$, Marika Rosa ${ }^{2},{ }^{1-2}$ Institute of Energy Systems and Environment, Riga Technical University
}

\begin{abstract}
Climate change and global warming has become one of the main topics worldwide. The European Union Emission Trading System (EU ETS) was established to limit climate change, providing regulations which encourage companies to invest in cleaner production and more energy efficient production. Latvian energy intensive enterprises are operating under the EU ETS from the year 2005.

The main goal of this paper is to provide an analysis of energy intensive installations in terms of their energy efficiency. Additionally, an analysis of EU ETS phase III which will start to operate in 2013 under new, more stringent rules has been conducted by modelling three Latvian energy intensive enterprise operations under this phase and estimating the barriers to meet the goal of the EU ETS phase III.
\end{abstract}

Keywords - Benchmarks, energy efficiency, energy intensive installations, European Union Emission Trading Scheme, Greenhouse gas emissions

\section{INTRODUCTION}

Climate change is progressing much faster than it was originally provided in scientist prognosis and climate models [2]. Climate change is mainly caused by human activities as a result of which large amount of greenhouse gasses are emitted [3]. Energy intensive installations ${ }^{1}$ are responsible for approximately $50 \%$ of the total GHG emissions in the European Union [4].

The EU Emission Trading System (ETS) is a key tool for reducing industrial greenhouse gas emissions in a cost-effective way. The tool provides regulations which could encourage companies to invest in cleaner and more energy efficient production. Nonetheless, non-harmonized allocation rules in the Community for phases I and II of the EU ETS led to a huge amount of over-allocated amount of allowances and did not produce the expected results [2,5].

Comparing National Allocation Plans (NAPs) and annual verified data, in the phase I, 30\% more allowances were granted than needed for all installations in Latvia, and in the first two years of phase II - 19\% more allowances. A comparison of the energy intensive production installations, which are operating under EU ETS from the year 2005 and have not left the system, $17 \%$ more allowances were granted in the phase I, and in phase II - $16 \%$ more allowances than it was verified.

Phase III will start to operate in 2013 under stricter rules. New provisions take into account questions about energy efficiency, cleaner production and the new technology use in

\footnotetext{
${ }^{1}$ Energy intensive installations - installations which consume large amount of primary energy and emit large amounts of greenhouse gas emissions during their operation. For example, metal production and processing sector, pulp and paper production sector.
}

practice. Allowances will be allocated using benchmarks which are based on $10 \%$ of the best installations of each sector in EU. In addition to the benchmarking method, the linear reduction factor of 1.74 will be applied to reach the EU goal - a $20 \%$ emission cut in 2020, compared to the year 1990.

In order to develop a better understanding of the EU ETS development period post-2013 and the impact on Latvian energy intensive enterprises, an analysis of three enterprises was conducted.

\section{ENTERPRISE PROFILE}

There are 10 installations that correspond to the requirements of ETS in Latvia. These companies represent the following sectors:

- $\quad$ Celluloses and paper production (1 installation);

- $\quad$ Steel casting (1 installation);

- $\quad$ Cement and lime production (2 installations);

- $\quad$ Glass and glass fibre production (1 installation);

- Ceramic manufacturing (5 installations).

All Latvian enterprises, in comparison with other enterprises of the same sector in EU, are considered to be of a small scale [6]. The annual carbon dioxide emissions of only two enterprises in Latvia (cement factory Cemex and steel production company Liepajas Metalurgs (LM)) reach $30 \mathrm{ktCO}_{2}$. All other eight installations in Latvia are small and medium scale enterprises with the annual $\mathrm{CO}_{2}$ emissions of less than 10 $\mathrm{ktCO}_{2}$ (see Figure 1).

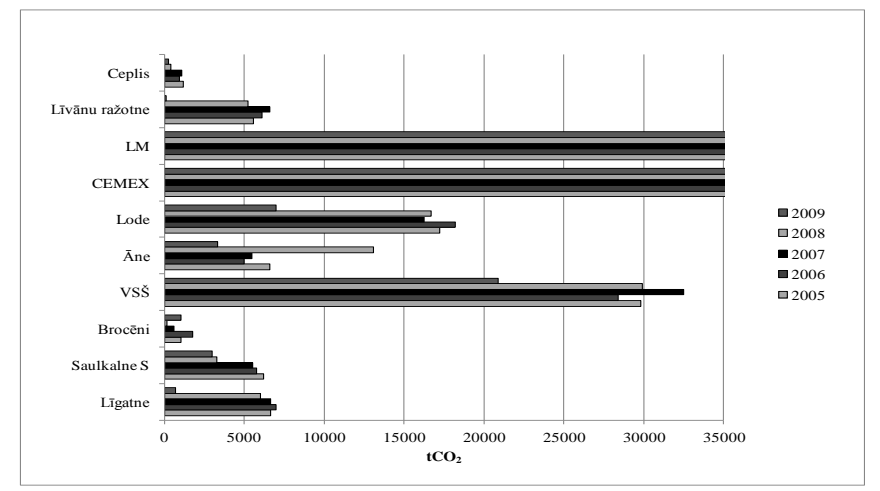

Fig.1. Verified annual emissions of 10 energy intensive industries in Latvia [1].

During phase I, installations have used around $83 \%$ of the allocated emission allowances. In 2008 and 2009, installations have used $84 \%$ of the annually allocated emission allowances for the period 2008-2012. 


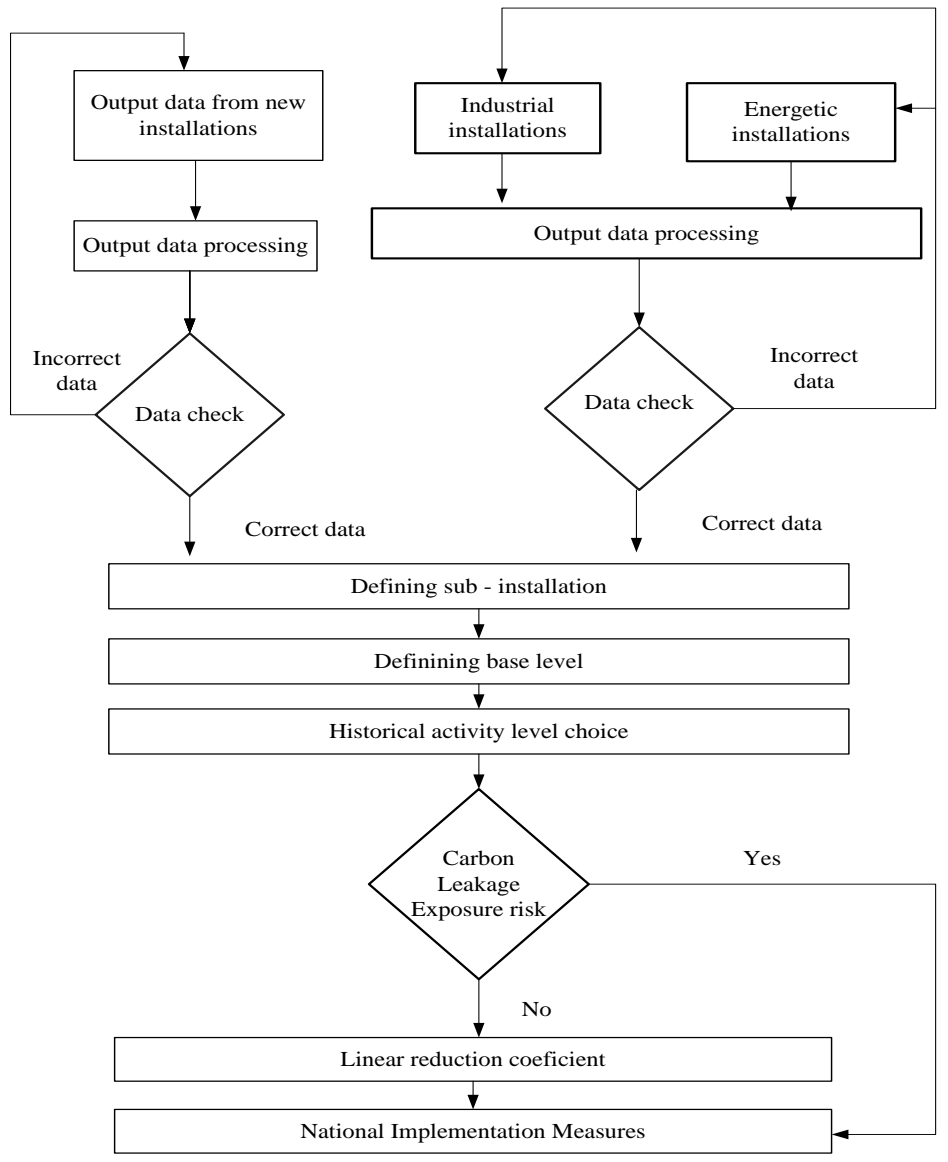

Fig.2. Algorithm for allocation methodology in the phase III.

\section{Methodology}

\section{A. Allocation methodology at the national level}

The allocation methodology at the national level is illustrated by the algorithm shown in Figure 2 .

In comparison with phases I and II, new allocation rules will come into force for phase III. The number of allowances will be calculated basing on the end product amount in each installation, rather than on the used fuel amounts in installation.

The number of sub-installations can vary from 1 to $n$, and the boundaries of each sub-installation can be determined using benchmarks (see chapter III section B). The boundaries of each sub-installation can be wider than the process boundaries. In the calculation of total allowances, it should be considered that the benchmark is constant for years 2013 - 2020.

Additional to the benchmark, the Carbon Leakage Exposure Factor (CLEF) will be applied, and it can vary between 2013 and 2020 [7]. The CLEF is defined for the installations which can suffer a material competitive disadvantage because of those installations which operate outside the European Union and which are not subject to emission reduction commitments [16].

Carbon leakage exposure factor values are summarized in Table 1.
TABLE 1

CARbon Leakage ExPosure FaCtor values $[9,16]$

\begin{tabular}{|c|c|c|c|c|c|c|c|c|}
\hline & $\stackrel{m}{\bar{乛}}$ & $\underset{\mathbb{8}}{\mathbb{8}}$ & $\frac{n}{8}$ & 를 & $\frac{N}{\bar{\gamma}}$ & $\frac{\infty}{\bar{\rho}}$ & 을 & త్ \\
\hline $\begin{array}{l}\text { Installations } \\
\text { with CLEF }\end{array}$ & - & - & - & - & - & - & - & - \\
\hline $\begin{array}{l}\text { Installations } \\
\text { which are not } \\
\text { the subject of } \\
\text { CLEF }\end{array}$ & $\begin{array}{l}8 \\
8 \\
\infty \\
0\end{array}$ & $\begin{array}{l}\stackrel{0}{\mathbb{N}} \\
\stackrel{0}{0}\end{array}$ & $\begin{array}{l}\bar{n} \\
0 \\
0 \\
0\end{array}$ & $\begin{array}{l}n \\
\infty \\
n \\
n\end{array}$ & $\frac{\tilde{\vartheta}}{\tilde{y}}$ & $\begin{array}{l}\stackrel{\Im}{+} \\
\stackrel{+}{0}\end{array}$ & 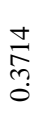 & 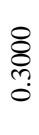 \\
\hline
\end{tabular}

Sub-installations which are the subject of carbon leakage exposure risk will receive a full amount of allowances at the benchmark level, while installations which are not the subject of carbon leakage exposure risk, will have the linear reduction factor applied [9,16,17]. In total, there are 164 sectors determined based on NACE and PRODCOM codes, which have Carbon Leakage Exposure risk in the EU [16,17].

\section{B. Benchmarks in phase III and allocation methodology at the installation level}

To ensure common and harmonized allocation rules for all installations in different Member States, a benchmark has been set for each end product $[8,9,10]$. Values are set according to the level of $10 \%$ of the best facilities in each sector in the years 2007 and 2008 [11-14]. 
For free allowance determination in installations, three types of benchmarks are used $[7,9,15]$ :

1. Product benchmark - the amount of free allocation is based on specific emissions at product level ( $\mathrm{tCO}_{2} / \mathrm{t}$ product);

2. Heat benchmark is fixed benchmark $62.3 \mathrm{tCO}_{2} / \mathrm{TJ}$ of heat consumed and allocation is based on the amount of measurable heat consumed;

3. Fuel benchmark is fixed benchmark $56.1 \mathrm{tCO}_{2} / \mathrm{TJ}$ of fuel used and allocation is based on the amount of fuel consumed.

Each installation has inputs and outputs that are eligible for free allocation and will receive allocation based on at least one of the benchmark methodologies, taking into account the benchmark system boundaries [7].

The product benchmark system boundaries are defined in Figure 3 and the free allowances are determined based on the production amounts [7].

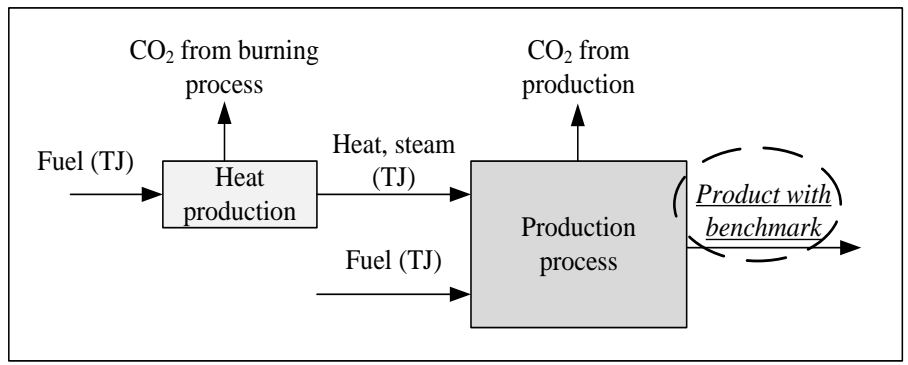

Fig.3. Product benchmark system boundaries [7].

The product benchmark system includes physical parameters - heat energy, fuel consumption for a certain kind of product manufacture, i.e. all carbon dioxide emissions from the production of a certain type of product are expressed in one benchmark. This benchmark will be used to determine free allowances in installation. All other processes which are not covered by the product benchmark will be covered by one of the other two types of benchmark - heat or fuel.

The heat benchmark system boundaries are defined in Figure 4. It is suitable for installations and sub-installations which are not covered by the product benchmark or the heat energy is end use product and the free amount of allowances are determined based on produced heat amount which is measurable and determined by meters [7].

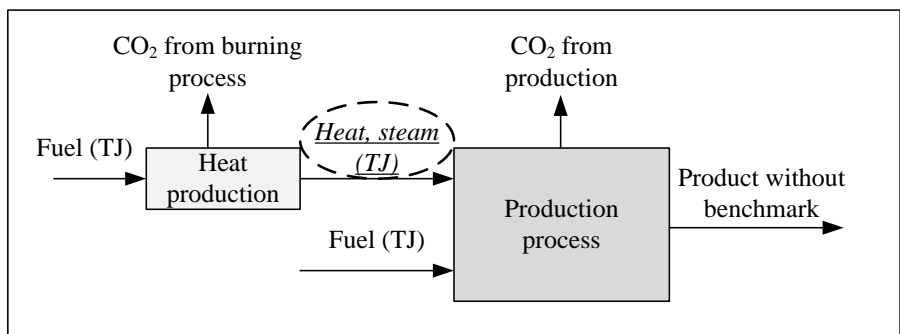

Fig.4. Heat benchmark system boundaries [7].

The fuel benchmark system boundaries are defined in Figure 5. A free amount of allowances is determined based on the fuel amount, which is expressed in terra joules (TJ) and is applied to the product installation which is not covered by the product benchmark and heat energy is the end product, but it is not measurable [7].

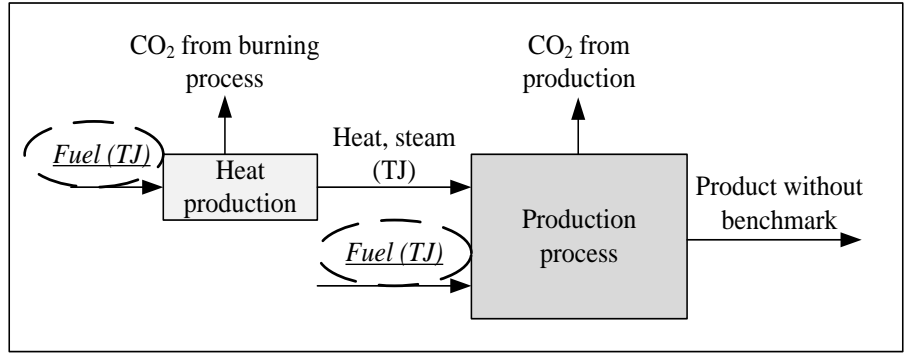

Fig.5. Fuel benchmark system boundaries [7].

The preliminary free allocation for all sub-installation types $\left(\mathrm{F}_{\text {sub }}\right)$ can be calculated taking into account the historical activity level (HAL) in each sub-installation, multiplying it by the product, heat or fuel benchmark (BM), and it can be expressed as [7]:

$$
F_{\text {sub }}=B M \cdot H A L
$$

The historical activity level (HAL) is the median annual production in the baseline period from 2005 - 2008 or 2009 2010. As the base period chose time period which describes the highest activity level. If one installation is divided in many subinstallations, one base period must be chosen for all subinstallations, regardless of whether the highest activity level of some sub-installations may occur at different time periods [7].

The preliminary total annual amount of allowances can be calculated by multiplying the allocation with the carbon leakage exposure factor (CLEF) of each sub-installation [7]:

$$
F_{\text {inst }}(k)=\sum_{i}\left(F_{\text {sub }}^{i} \times C L E F_{\text {sub }}^{i}(k)\right)^{2}
$$

\section{RESULTS}

The analysis of 3 Latvian energy intensive enterprises under the EU ETS phase III was made based on data availability.

\section{Allocation for company Saulkane $S$}

The main activity of the company Saulkalne $\mathrm{S}$ is the production of lime from dolomite. The primary production process begins with a raw material mixing process where the dolomite is mixed together with fuel and is transferred to the lime kiln. After firing, the lime is crushed and ground in the bullet mill.

$\mathrm{CO}_{2}$ emissions are emitted mainly from three installations the boiler, lime kiln and drying cylinders where coal and natural gas are used.

To determine preliminary free allocation for the installation, the installation was divided into three sub-installations:

1. Dolomite lime benchmark;

2. Fuel benchmark A;

\footnotetext{
2 For some sectors there is a need to use a specific free allowance determination methodology to ensure greenhouse gas emission efficiency.
} 
3. Fuel benchmark B.

The dolomite benchmark sub-installation covers all processes of lime production and all emissions from the entire process. The sub - installation boundaries are shown in Figure 6.

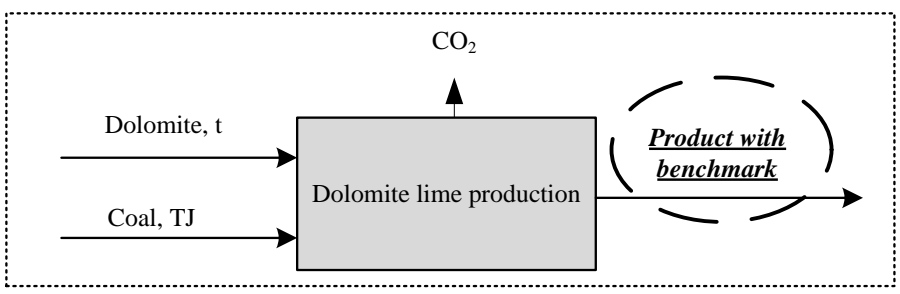

Fig.6. Dolomite benchmark sub - installation boundaries.

Natural gas is used in the production of other products. As the heat produced is not measured, a fuel benchmark is applied to this sub-installation. The system boundaries are shown in Fig. 7.

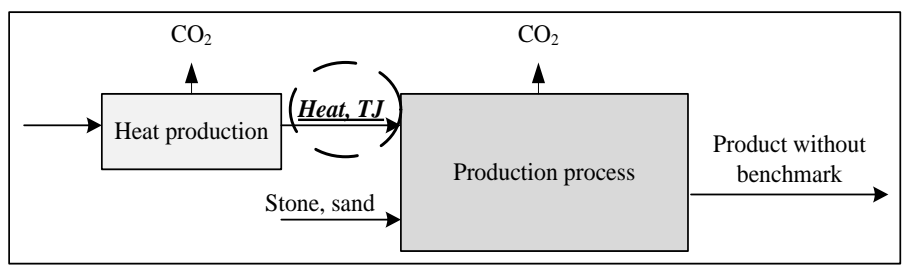

Fig.7. Fuel benchmark sub - installation A.

Natural gas is also used for internal heating needs of the facility. The heat produced is not measured and therefore the fuel benchmark is applied to this sub-installation. The system boundaries are shown in Figure 8.

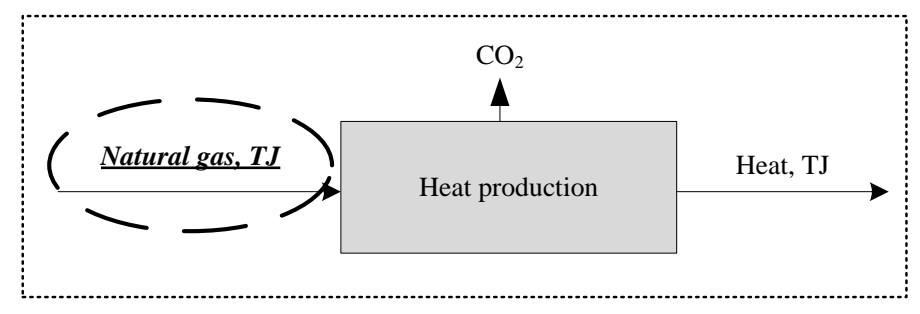

Fig.8. Fuel benchmark sub - installation B.

In order to ensure greenhouse gas emission efficiency from the lime production process, there is a need for a historical activity level correction and this can be done by applying formula $[9,18]$ :

$$
H A L_{s \tan d a r t}=\operatorname{medium}\left(\frac{785 \cdot m_{\mathrm{CaO}, k}+1092 \cdot m_{\mathrm{MgO}, k}}{865,6} \cdot H A L_{\mathrm{lim} e k}\right)
$$

where

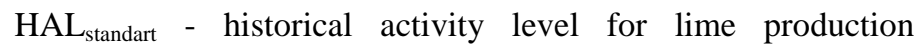
expressed in tonnes of standard pure lime.

$\mathrm{m}_{\mathrm{CaO}, \mathrm{k}}$ - content of free $\mathrm{CaO}$ in the produced lime in year $\mathrm{k}$ of the baseline period expressed in mass \%. If there is no data available then the $52 \%$ value is used.

$\mathrm{m}_{\mathrm{MgO}, \mathrm{k}}$ - content of free $\mathrm{MgO}$ in the produced lime in year $\mathrm{k}$ of the baseline period expressed in mass \%. If there is no data available then the $33 \%$ value is usedHAL $\mathrm{L}_{\text {limek }}-$ uncorrected historical activity level for lime production in year $\mathrm{k}$ expressed in tonnes of lime.

As there is no data available on the free $\mathrm{CaO}$ and $\mathrm{MgO}$ content in the dolomite used for lime production at Saulkalne S, some assumptions were made. For data correction, the minimal accepted free content values were used:

$$
\begin{aligned}
& \text { - } \mathrm{m}_{\mathrm{CaO}}=52 \% \\
& \text { - } \mathrm{m}_{\mathrm{MgO}}=33 \% \text {. }
\end{aligned}
$$

The base year of the installation was $2005-2008$.

The preliminary free allocation for each sub-installation can be calculated using equation (1) and the fuel benchmark value $\mathrm{BM}=56.1 \mathrm{tCO}_{2} / \mathrm{TJ}$ and the dolomite benchmark value $-\mathrm{BM}=$ $1.072 \mathrm{tCO}_{2} /$ tonne production. Product benchmark subinstallation preliminary annual allocation is equal to 1926 allowances, fuel benchmark sub-installation $\mathrm{A}$ is equal to 2781 allowances and fuel benchmark sub-installation B -67 allowances.

For the calculation of the preliminary total annual amount of allowances using formula (2), there is a need to determine the carbon leakage status for each sub-installation. Fuel benchmark sub-installations A and B (NACE code 4030) are not the subject of CLEF, the annual reduction coefficient will be applied (see Table 1). The product benchmark sub-installation (NACE code 2652 ) is the subject of CLEF and free allowances will be granted in full amount (CLEF=1).

An example of final free allocation calculation for installation for the year 2013 is shown below:

$$
F_{\text {inst }}(2013)=(278 \cdot 0.8)+(67 \cdot 0.8)+(1926 \cdot 1)=4205 \text { allowances }
$$

All calculated free allowances are summarized in Table 2.

\section{Allocation for enterprise Valmieras stikla sķiedra}

The main activity of Valmieras stikla šksiedra company is glass product manufacturing from glass fiber.

The glass fiber is produced from two different materials glass balls and batch. The production process of fiber from glass balls is conducted in a one-stage glass fiber plant, where glass fibre is produced straight from bath furnace feeder bushings. The heat for the process is obtained from natural gas, with the additional use of electrical heaters.

In 2006, a second one-stage glass fiber plant started to operate at the company, in which fiber is produced from batch where the main raw materials are quartz sand, kaolin, limestone, boric acid, spar, sodium sulfate and soda ash. The production process can be divided in several steps - preparation of batch, glass melting in bath furnace, feeder system, fiber development and fiber filament winding assemblies.

To determine preliminary free allocation in the installation, the installation needs to be divided into two sub-installations:

1. Continuous glass fiber benchmark; and

2. Fuel benchmark.

The continuous glass fiber benchmark sub-installation includes all fiber production processes, beginning from raw material melting till glass fiber production process, and covers all emissions from the specific material and fuel burning processes. All other production steps - drying, weaving and spinning are not included in the continuous glass fiber 
benchmark sub-installation. The sub-installation boundaries are shown in Figure 9.

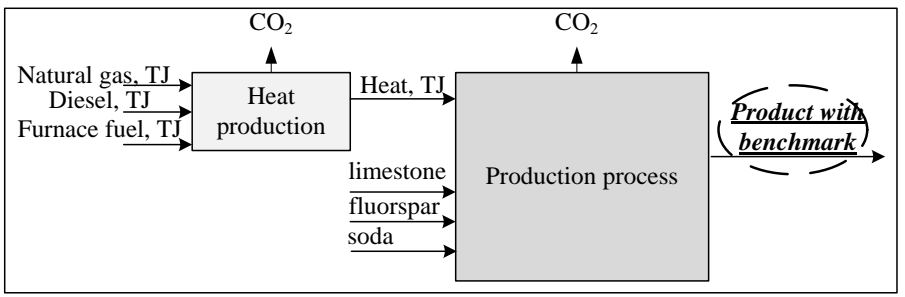

Fig.9. Product benchmark sub - installation system boundaries.

Due to the fact that this enterprise does not have a heat meter, and no data is available for fuel used in the operation of the equipment, machines which are not covered with the product benchmark will be covered by the fuel benchmark. When more data are available, there will be a need to divide this subinstallation into smaller systems. The fuel benchmark system boundaries are shown in Figure 10.

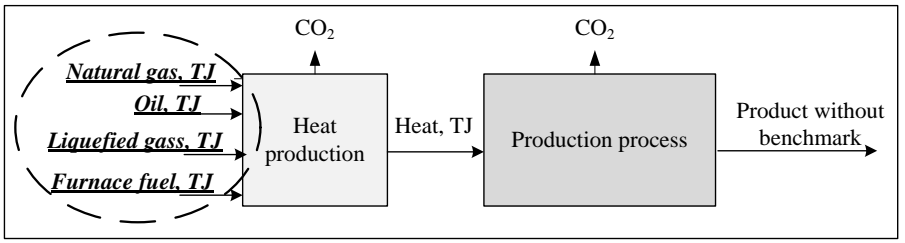

Fig.10. Fuel benchmark sub - installation boundaries.

The base period of the installation was 2005-2008, as there were no data available for the years 2009 and 2010 .

The preliminary free allocation for each sub-installation can be calculated using equation (1) and the fuel benchmark value $\mathrm{BM}=56.1 \mathrm{tCO}_{2} / \mathrm{TJ}$ and the continuous glass fiber benchmark value $-\mathrm{BM}=0.406 \mathrm{tCO}_{2} /$ tonne production. The preliminary annual allocation of the sub-installation of the product benchmark is equal to 7431 allowances, but in the fuel benchmark sub - installation - 7434 allowances.

For calculation of the preliminary total annual amount of allowances using formula (2), there is need to determine carbon leakage status for each sub-installation. The fuel benchmark sub-installation (PRODCOM code 28.30.11.) is not the subject of CLEF, and, therefore, the annual reduction coefficient will be applied (see Table 1). The product benchmark sub-installation (PRODCOM code 26.14.11.) is the subject of CLEF and free allowances will be granted in the full amount (CLEF=1).

An example of final free allocation calculation for an installation for the year 2013 is shown below:

$$
F_{\text {installation }}(2013)=(7434 \cdot 0,8)+(7431 \cdot 1)=13378 \text { allowances }
$$

All calculated free allowances are summarized in Table 2.

\section{E. Allocation for enterprise Cemex}

The enterprise Cemex is a cement producer known worldwide. The main production process can be divided in several steps - raw material treatment, clinker burning and cement production. At the raw material treatment step, all materials are dried, minced and preburned. The next step is the clinker burning step where different fuels are used. The company has a newly built factory operating from 2009 which, in addition to fossil fuels, uses refuse-derived fuel (RDF) and used tires. The temperature at this step reaches $1450^{\circ} \mathrm{C}$. At the end, the clinker is cooled and crushed.

To determine preliminary free allocation for the installation, the installation was encompassed as one gray clinker benchmark which includes all emissions from the production process. The system boundaries are shown in Figure 11.

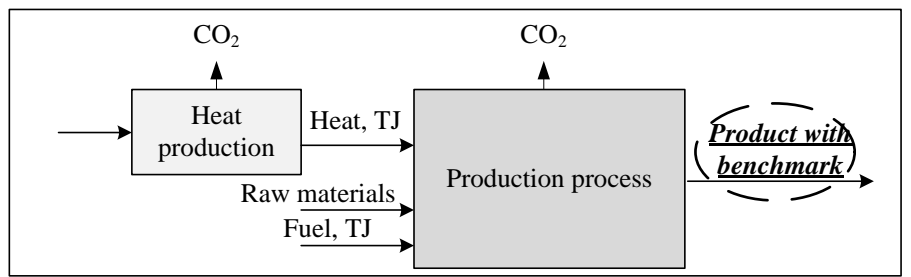

Fig.11.Product benchmark system boundaries.

The base period of the installation was 2005-2008, as there were no data available for the years 2009 and 2010 .

The preliminary free allocation for each sub-installation can be calculated using equation (1) and the gray clinker benchmark value $-\mathrm{BM}=0.766 \mathrm{tCO}_{2} /$ tonne production, the preliminary annual allocation is equal to 244598 allowances.

For the calculation of the preliminary total annual amount of allowances using equation (2), there is a need to determine carbon leakage status for the sub-installation. The product benchmark sub-installation (PRODCOM code 26.51.12.) is the subject of CLEF and free allowances will be granted in the full amount $(\mathrm{CLEF}=1)$.

An example of the final free allocation calculation for installation for the year 2013 is shown below:

$$
F_{\text {installaton }}(2013)=244598 \cdot 1=244598 \text { allowances }
$$

A comparison of the annual allowances in the three enterprises is shown in Table 2.

TABLE 2

\begin{tabular}{|c|c|c|c|c|c|c|c|c|c|}
\hline & & $\overline{\bar{\tau}}_{\text {m }}$ & $\overline{\bar{d}}_{\nabla}$ & $\overline{\bar{\nu}}_{\text {in }}$ & $\overline{\bar{\nu}}_{\text {。 }}$ & $\overline{\bar{\tau}}_{\text {N }}$ & $\overrightarrow{\bar{\nu}}_{\infty}$ & $\overline{\bar{\tau}}_{a}$ & $\widetilde{\mathcal{I}}_{\ominus}$ \\
\hline \multirow{3}{*}{ 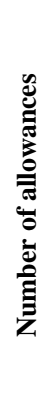 } & 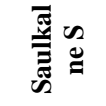 & 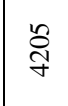 & ঠ̊ & 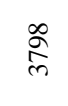 & 古 & बे & $\frac{\infty}{\infty}$ & $\begin{array}{l}+ \\
\stackrel{\text { సे }}{ }\end{array}$ & 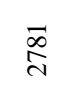 \\
\hline & 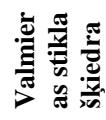 & $\stackrel{\infty}{\stackrel{\infty}{m}}$ & $\begin{array}{l}\text { 广્f } \\
\text { త్ }\end{array}$ & $\frac{n}{\stackrel{n}{c}}$ & $\begin{array}{l}n \\
\stackrel{\infty}{=} \\
=\end{array}$ & $\stackrel{\mathbb{n}}{\stackrel{\Xi}{=}}$ & 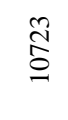 & $\stackrel{\bar{\sigma}}{0}$ & $\overline{6}$ \\
\hline & نัّ & \begin{tabular}{l}
$\infty$ \\
$\stackrel{n}{2}$ \\
\multirow{2}{*}{}
\end{tabular} & \begin{tabular}{l}
$\infty$ \\
$\stackrel{2}{7}$ \\
\multirow{2}{*}{}
\end{tabular} & 竎 & $\begin{array}{l}\text { in } \\
\text { in }\end{array}$ & \begin{tabular}{l}
$\infty$ \\
$\stackrel{n}{7}$ \\
\multirow{2}{*}{}
\end{tabular} & 年 & \begin{tabular}{l}
$\infty$ \\
$\stackrel{2}{2}$ \\
\multirow{2}{*}{}
\end{tabular} & \begin{tabular}{l}
$\infty$ \\
$\stackrel{2}{n}$ \\
\multirow{2}{*}{}
\end{tabular} \\
\hline
\end{tabular}

ANNUAL FREE ALLOWANCES

The total amount of allowances for 2013-2020 of the enterprise Saulkalne $\mathrm{S}$ will be 27944, of Valmieras stikla şkiedra - 92153 and of Cemex - 2201382 allowances. 


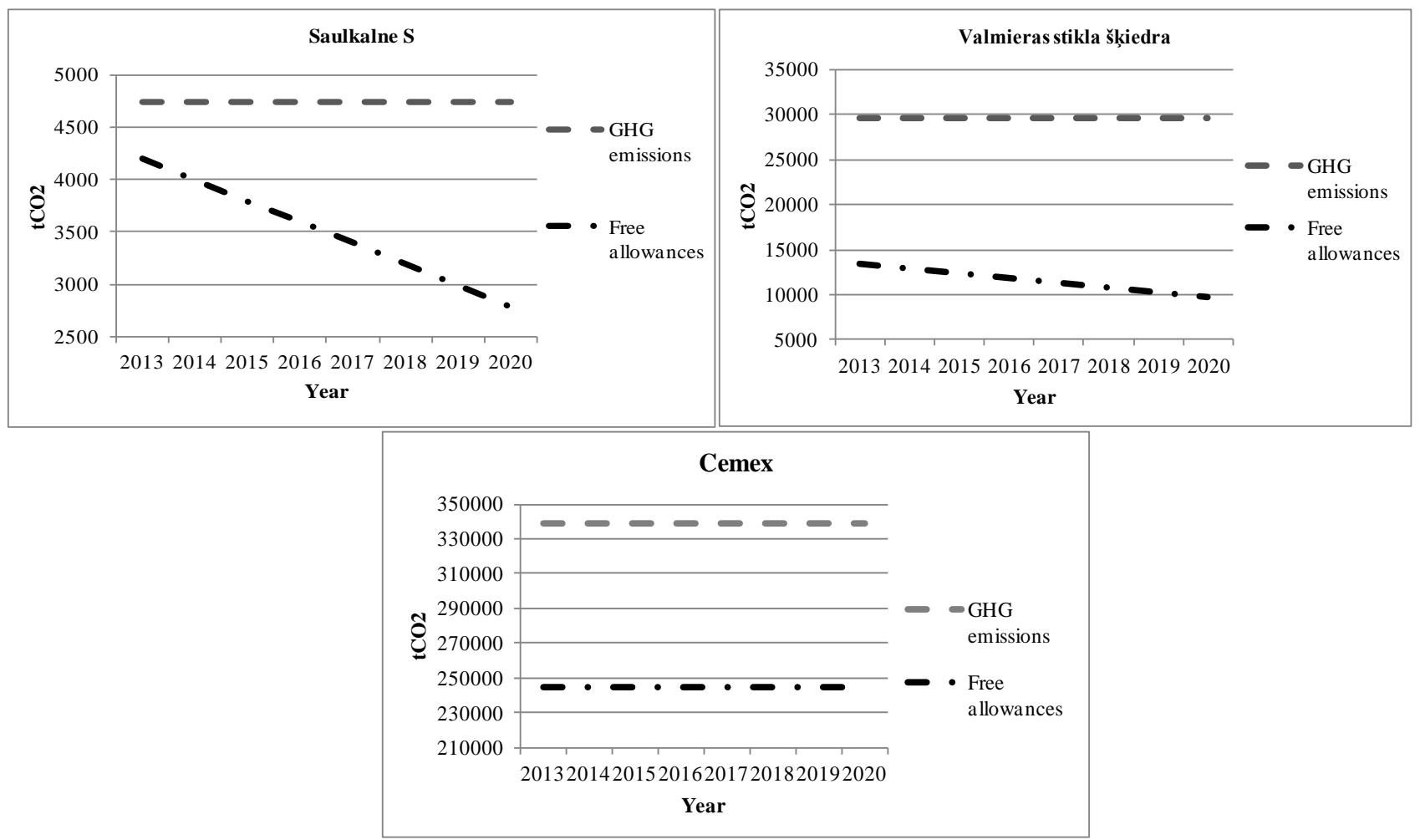

Fig.12. Comparison of annual emissions and free allowances.

\section{F. Greenhouse gas emission prognosis}

Assuming that production amounts in the future will remain constant at the historical activity level, greenhouse gas amounts emitted in each enterprise can be determined using the formula:

$$
G H G=H A L \cdot R \cdot P
$$

where

$\mathrm{GHG}$ - emitted greenhouse gas emissions, $\mathrm{tCO}_{2}$

HAL - historical activity level, TJ

$\mathrm{R}$ - Emission factor, $\mathrm{tCO}_{2} / \mathrm{TJ}$

$\mathrm{P}$ - Oxidation factor.

Oxidation and emission factor values for the annual greenhouse gas emission calculation are taken from 2004/156/EC: Commission Decision of 29 January 2004 establishing guidelines for the monitoring and reporting of greenhouse gas emissions pursuant to Directive 2003/87/EC of the European Parliament and of the Council [20].

The annual greenhouse gas emission amount and the free allocation comparison in each enterprise is shown in Figure 12.

Based on the assumptions made, the enterprise Saulkalne $\mathrm{S}$ annually will report $4808 \mathrm{tCO}_{2}$ emissions, Valmieras stikla šķiedra - $29633 \mathrm{tCO}_{2}$, and Cemex - $338425 \mathrm{tCO}_{2}$ emissions.

Already in the first year of EU ETS phase III, Saulkalne S will have to purchase additional $13 \%$ of allowances, and in 2020 this amount will increase up to $42 \%$. According to the calculations, the installation will have to buy more than 10500 allowances during phase III.
In the first year of EU ETS phase III, the enterprise Valmieras stikla šķiedra will have to purchase additional $55 \%$ of allowances, and in 2020 this amount will increase up to $76 \%$, while the enterprise Cemex will have to purchase additional $21 \%$ allowances in the year 2013 - a total of 844443 allowances.

The latest projections indicate that one allowance in 2013 will cost $30 €$, and the price will increase annually by $2 €$. The allowance price projections are summarized in Table 3 .

TABLE 3

PRICES OF EMISSION ALLOWANCES IN 2013-2020 [19]

\begin{tabular}{|c|c|c|c|c|c|c|c|c|}
\hline$\stackrel{\nexists}{\rightleftarrows}$ & $\stackrel{\text { లె }}{\bar{乛}}$ & 龒 & 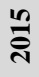 & 를 & 공 & 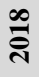 & $\hat{\bar{ন}}$ & ণิ \\
\hline 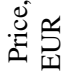 & లి & N & ले & ల) & $\stackrel{\infty}{m}$ & fo & $\stackrel{F}{f}$ & 寸 \\
\hline
\end{tabular}

Using the calculated emission amounts in each enterprise which companies will need to purchase and the emission allowance price prognosis, it is possible to determine the total investments needed by each enterprise for the purchase of allowances.

The total investments needed for the purchase of allowances in the enterprise are calculated and summarized in Figure 13. 


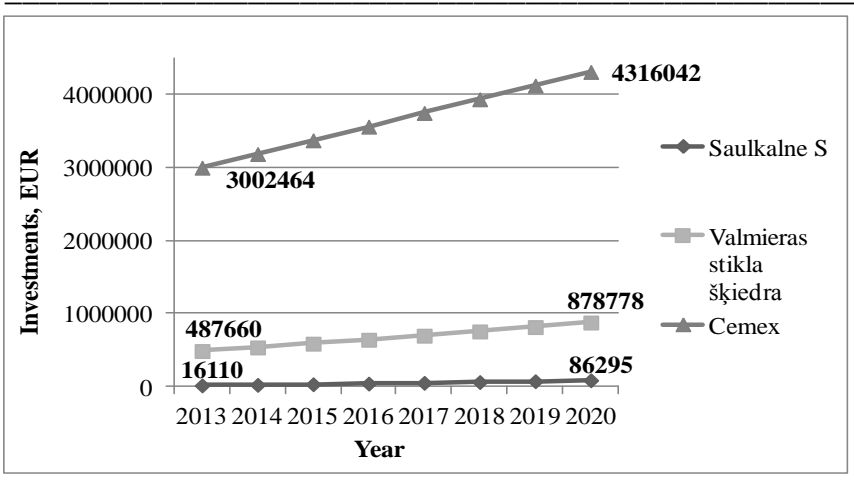

Fig.13. Investments for the purchase of allowances.

In the enterprise Saulkalne $\mathrm{S}$, the total annual investments for the purchase of allowances in the market may reach $406 \mathbf{k €}$; in the enterprise Valmieras stikla šksiedra the total annual

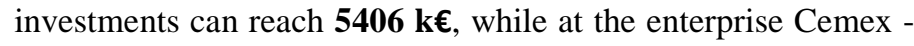
$3.2 \mathrm{~m} €$.

\section{CONCLUSIONS}

Each enterprise needs specific data for EU ETS phase III which differ from the data that EU member state governments have collected up to now for the National Allocation Plans (NAP). The cornerstone of the methodology is the use of benchmarks which are developed basing on $10 \%$ of the most energy efficient enterprises in each sector in EU.

Latvian energy intensive production enterprises will face several problems operating under EU ETS, compared to other enterprises in the EU, since Latvian enterprises have low energy efficiency.

In the time of global economical recession, many companies have faced economic problems and do not have financial resources to spare for investment. Low efficiency will lead to additional investments for the use of allowances in the market and can be an issue of the enterprise's ability to stay competitive.

\section{REFERENCES}

1. Latvian energy intensive enterprise greenhouse gas emission annual reports

2. Klepper, G. The future of the European Emission Trading System and the Clean Development Mechanism in a post-Kyoto world // Energy Economics. - (2011), doi:10.1016/j.eneco.2010.12.014.

3. IPCC, 2007: Summary for Policymakers. In: Climate Change 2007: The Physical Science Basis. Contribution of Working Group I to the Fourth Assessment Report of the Intergovernmental Panel on Climate Change [Solomon, S., D. Qin, M. Manning, Z. Chen, M. Marquis, K.B. Averyt, M.Tignor and H.L. Miller (eds.)]. Cambridge University Press, Cambridge, United Kingdom And New York, NY, USA

4. Egenhofer, C. The Making of the EU Emission Trading Scheme: Status, Prospects and Implication for Business // European Managemenet Journal - 6. (2007) pp 453 - 463

5. Skjǽrseth, J.B., Wettestand, J. Making the EU Emission Trading System: The European Commission as an entrepreneurial epistemic leader // Global Environmental Change. - 20.(2010) pp 314-321.

6. Ecofys, Fraunhofer ISI, Oko- Institut, Methodology for the free allocation of emission allowances in the EU ETS post 2012. Sector report for the lime industry. - EC, November 2009 - p 20

7. EC DIRECTORATE - GENERAL CLIMATE ACTION, Directorate B - European \& International Carbon Markets, Guidance Document $\mathrm{n}^{\circ} 2$ on the harmonized free allocation methodology for the EU - ETS post 2012. General guidance on allocation methodologies. - EC, 2011 - p 55.
8. Ecofys, Fraunhofer ISI, Oko- Institut, Methodology for the free allocation of emission allowances in the EU ETS post 2012. Report on the project approach and general issues. - EC, November 2009 - p 209.

9. EC, draft Commission decision of determing transitional Union - wide rules of the harmonized free allocation of emission allowances pursuant to Article 10a of Directive 2003/87/EC, version of 15 December 2010.

10. CAN Europe, Innovation. Position paper on Benchmarking and allocation rules in phase III of the EU Emission Trading System. - CAN, 2010.

11. Bruyn, de S., Markowska, A., Nelissen, D., Will the energy - intensive industry profit from EU ETS under the phase 3? Impacts of EU ETS on profits, competitiveness and innovation. - Delft, 2010 - 53 p.

12. Sijm, J.P.M., Berk, M.M., Elzen, den M.G.J., Options for post -2012 EU burden sharing and EU ETS allocation. - WAB, $2007-80$ p.

13. Direktīva 2009/29/EK (2009.gada 23.aprīlis) ar ko Direktīvu 2003/87/EK groza, lai uzlabotu un paplašinātu Kopienas siltumnīcas efektu izraisošo gāzu emisiju kvotu tirdzniecības sistēmu.

14. EC, Draft Commission decision in free allocation rules for the emissions trading scheme ('benchmarking decision'), February 8, 2011 - p 5.

15. EC DIRECTORATE - GENERAL CLIMATE ACTION, Directorate B European \& International Carbon Markets, Guidance Document $n^{\circ} 1$ on the harmonized free allocation methodology for the EU - ETS post 2012. General guidance to the allocation methodology. - EC, 2011 - p 25.

16. EC DIRECTORATE - GENERAL CLIMATE ACTION, Directorate B European \& International Carbon Markets, Guidance Document $n^{\circ} 5$ on the harmonized free allocation methodology for the EU - ETS post 2012. Guidance on carbon leakage. - EC, 2011 - p 13.

17. Commission Decision of 24 December 2009 determing, pursuant to Directive 2003/87/EC of the European Parliament and of the Council, a list of sectors and subsectors which are deemed to be exposed to a significant risk of carbon leakage, (2010/2/EU)

18. EC DIRECTORATE - GENERAL CLIMATE ACTION, Directorate B European \& International Carbon Markets, Guidance Document $\mathrm{n}^{\circ} 9$ on the harmonized free allocation methodology for the EU - ETS post 2012. Sector - specific guidance. - EC, 2011 - p 154.

19. Janet, E. Milne, THE REALITY OF CARBON TAXES IN THE 21ST CENTURY. - A Joint Project of the Environmental Tax Policy Institute and the Vermont Journal of Environmental Law Vermont Law School, 2009 - p 114

20. 2004/156/EC: Commission Decision of 29 January 2004 establishing guidelines for the monitoring and reporting of greenhouse gas emissions pursuant to Directive 2003/87/EC of the European Parliament and of the Council.

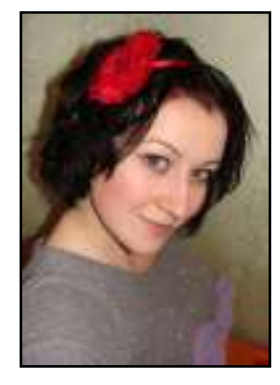

Dace Zahare, M.sc., scientific assistant, Riga Technical University, Environmental Protection and Heating System Institute. Dace Zahare has been part of scientific staff of Faculty of Energy and Electronics, Riga Technical University since 2010. The main research area are cleaner production and energy efficiency. She has participated in several local and international projects related to renewable energy resources and energy efficiency. She has Master of Environmental science diploma. Master thesis "Analysis of energy intensive eneterprise activity in European Union Emission Trading system from year 2005 till 2020" was defended in Faculty of Energy and Electronics, Riga Technical University (2011).

Address: Kronvalda Boulevard 1, Riga, LV-1010, Latvia

Phone: +37167089088, Fax: +37167089908

E-mail: dace.zahare@rtu.lv

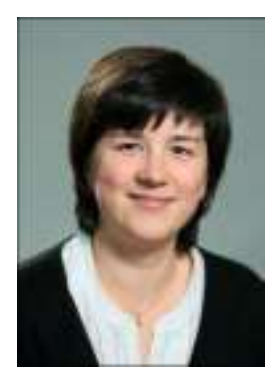

Marika Rosa, Dr.sc. ing., asoc.proffesor, Riga Technical University, Environmental Protection and Heating System Institute. Marika Rochas has been part of academic staff of Faculty of Energy and Electronics, Riga Technical University since 2003. The main research area are cleaner production and energy efficiency. She has participated in different local and international projects related to energy and environment. She has Doctor. PhD thesis "Analysis of mechanisms for $\mathrm{CO}_{2}$ emission reduction in Latvian energy installations" was defended in Faculty of Power and Electrical Engineering, Riga Technical University (2006).

Address: Kronvalda Boulevard 1, Riga, LV-1010, Latvia 
Phone: +371 67089088, Fax: +37167089908

E-mail: marika.rosa@rtu.lv

Dace Zahare, Marika Rošā. Latvijas energointensīvo uzṇēmumu analīze ES emisiju tirdzniecības sistēmā

Energointensīvie ražošanas uzņēmumi ir atbildīgi par aptuveni pusi no siltumnīcefekta izraisošo gāzu emisijām pasaulē. Lai ma zinātu uzņēmuma darbības rezultātā radīto ietekmi, nepārtraukti tiek izstrādāti un piennemti jauni, stingrāki noteikumi vides aizsardzības jomā. Eiropas Savienības emisiju tirdzniecības sistēma ir lielākā no sistēmām, kas kontrolē lielos emitētājus Eiropā. Pētījuma galvenais mērķis ir Latvijas en ergointensīvo ražošanas uznēmumu darbības efektivitātes analīze kopš Eiropas Savienības Emisijas tirdzniecības sistēmas sākuma 2005.gadā. Papildus, izmantojot jauno starptautisko kvotu piešķiršanas metodiku trešajam emisiju tirdzniecības sistēmas darbības periodam, kas sāksies 2013.gadā, ir veikts brīvo emisiju kvotu aprēḳins iekārtām, papildus prognozējot kvotu apjomus, kas uzn̄ēmumam būs jāiegādājas tirgū. Aprēḳins ir veikts 3 dažādiem Latvijas rūpniecības uznēmumiem: cementa ražošanas uzṇēmumam SIA „Cemex”, kaḷku ražošanas uzn̄ēmuma SAI „Saulkalne S” un stikla šḳiedra s ražošanas uzṇēmumam AS „Valmieras stikla šķiedra”.

Даце Захаре, Марика Роса. Анализ Латвийский энергоемких компаний в системе торговле эмиссий Европейского союза

Энергоемкие производственные предприятия ответственны за примерно половину выбросов парниковых газов в мире. В целях сокращения загрязнения природы постоянно разрабатываются новые более строгие правила. Система торговли эмиссий Европейского союза является крупнейшей из систем управления над основными источниками выбросов в Европе. Главная цель исследования - анализ эффективности работы Латвийских энергоемких производств с начала периода работы системы торговли эмиссий Европейского союза в 2005 году, дополнительно используя новую международную методологию распределения квот в третьем периоде, который начнется в 2013 году. Был произведен расчет объёма свободных эмиссий для оборудований, а также был произведен дополнительный прогноз объема квот, который предприятию придется приобрести на рынке. Расчет был произведен трем латвийским предприятиям: предприятию SIA “Сетех", которое занимается производством цемента, предприятию SAI "Saulkalne S", которое занимается производством извести и предприятию АS "Валмиерское стекловолокно", которое занимается производством стекловолокна. 